\title{
Analisis Metode Triage Prehospital pada Insiden Korban Masal (Mass Casualty Incident)
}

\author{
Oleh: Nuris Kushayati \\ Staf Pengajar Akademi Perawat Dian Husada Mojokerto
}

\section{Pendahuluan}

Triage sebagai pintu gerbang perawatan pasien memegang peranan penting dalam pengaturan darurat melalui pengelompokan dan memprioritaskan paien secara efisien sesuai dengan tampilan medis pasien. Triage adalah perawatan terhadap pasien yang didasarkan pada prioritas pasien ( atau korban selama bencana) bersumber pada penyakit/ tingkat cedera, tingkat keparahan, prognosis dan ketersediaan sumber daya. Dengan triage dapat ditentukan kebutuhan terbesar pasien/korban untuk segera menerima perawatan secepat mungkin. Tujuan dari triage adalah untuk mengidentifikasi pasien yang membutuhkan tindakan resusitasi segera, menetapkan pasien ke area perawatan untuk memprioritaskan dalam perawatan dan untuk memulai tindakan diagnostik atau terapi.

Perawat dalam melakukan pengkajian dan menentukan prioritas perawatan (triage) tidak hanya didasarkan pada kondisi fisik, lingkungan dan psikososial pasien tetapi juga memperhatikan patient flow di departemen emergensi dan akses perawat. Triage departemen emergensi memiliki beberapa fungsi diantaranya : 1) identifikasi pasien yang tidak harus menunggu untuk dilihat, dan 2) memprioritaskan pasien (Mace and Mayer, 2013). Berbagai macam sistem triage telah digunakan diseluruh dunia yaitu The Australian Triage Scale (ATS), The Manchester Triage Scale, The Canadian Triage and Acuity Scale (CTAS) dan Emergency Severity Index (ESI). CTAS (Canadian Triage and Acuity Scale) diakui sebagai sistem triage yang handal dalam penilaian pasien dengan cepat. Kehandalan dan validitasnya telah dibuktikan dalam triage pada pasien pediatrik dan pasien dewasa (Lee, Et al, 2011).

Menurut Lee, C.H., (2010) menerangkan pada situasi diklasifikasikan sebagai bencana masal atau MCI, membutuhkan metode triase cepat dan efektif. Dalam rangka mengoptimalkan hasil pasien secara keseluruhan dalam situasi bencana, ada pergeseran dari melakukan apa yang terbaik untuk setiap pasien untuk melakukan kebaikan terbesar untuk jumlah terbesar orang. Ada beberapa tumpang tindih dalam prinsip-prinsip dasar dari korban massal dan sistem triase bencana yang sedang digunakan di seluruh dunia, namun data efikasi masih terbatas dalam literature. Karena secara inheren sulit untuk menyelidiki dan membandingkan protokol bencana dengan menggunakan pendekatan berbasis bukti, 
tidak ada data yang pasti di mana teknik triase bencana akan menghemat jumlah terbesar korban. Saat ini, dua protokol triase paling umum diterima adalah START dan SALT.

\section{Model SALT Triage Untuk Insiden Korban Masal (Mass Casualty Incident)}

Lerner et al. Dalam Neal, D.J. (2009) menilai sistem triase yang saat ini digunakan dan menggambarkan kekuatan dan kelemahan dari sistem ini. Penelitian ini mengembangkan pedoman triase yang digunakan untuk semua bahaya dan dapat diterapkan pada orang dewasa dan anak-anak. SALT Triage singkatan (sort - assess lifesaving - interventions - treatment/transport). SALT terdiri dari dua langkah ketika menangani korban. Hal ini termasuk triase awal korban menggunakan perintah suara, perawatan awal yang cepat, penilaian masing-masing korban dan prioritas, dan inisiasi pengobatan dan transportasi. Pendekatan Triase SALT memiliki beberapa karakteristik tambahan. Pertama, SALT mengidentifikasi kategori expectant (hamil) yang fleksibel dan dapat diubah berdasarkan faktor-faktor tertentu. Kedua, SALT Triage awalnya mengkategorikan luka, tapi memberikan evaluasi sekunder untuk mengidentifikasi korban langsung.

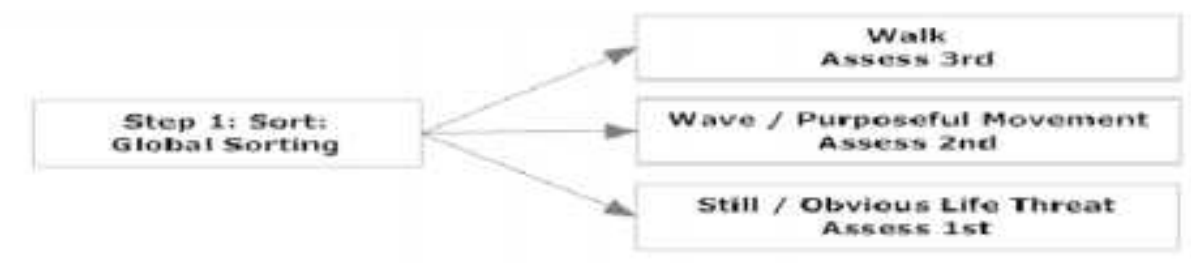

Step $2-$ Assess

Individual Assessment

Lifesaving

Interwentions:

Contral major hemarrhage

Open airway (it chiles

consider 2 rescue breaths)

Chest decampression

Auto injector aritidotes
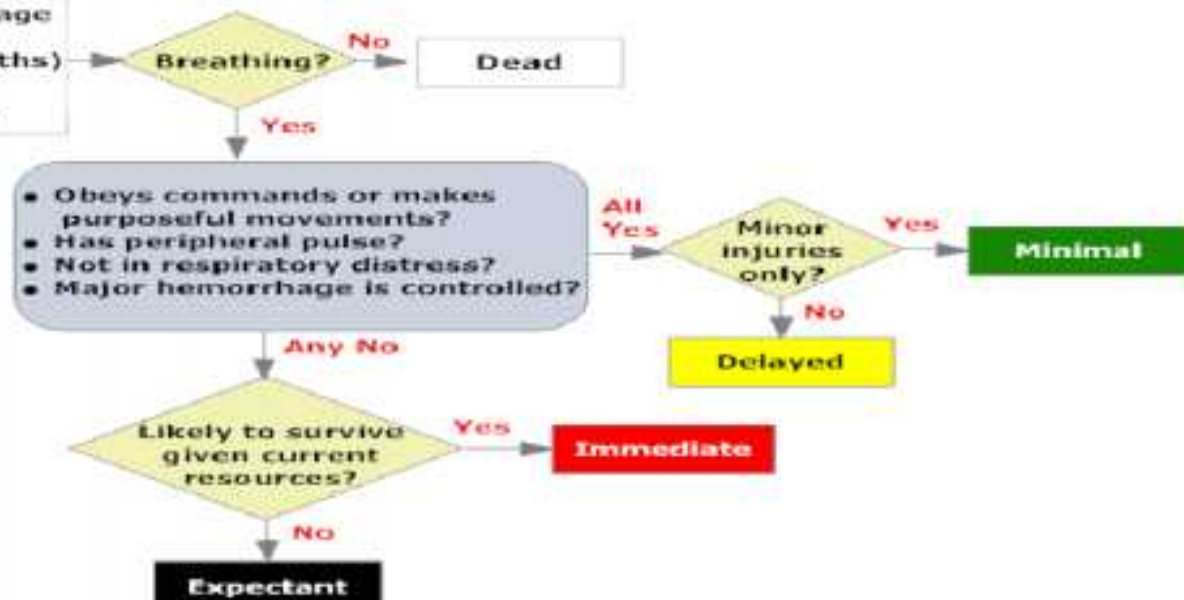

Expectant

Gambar 1. SALT triage algorithm. LSI = lifesaving interventions 


\section{Step 1 : SORT}

SALT dimulai dengan menyortir pasien secara global melalui penilaian korban secara individu. Pasien yang bisa berjalan diminta untuk berjalan ke suatu area tertentu dan dikaji pada prioritas terakhir untuk penilaian individu. Penilaian kedua dilakukan pada korban yang diminta untuk tetap mengikuti perintah atau di kaji kemampuan gerakan secara terarah / gerakan bertujuan. Pada korban yang tetap diam tidak bergerak dari tempatnya dan dengan kondisi yang mengancam nyawa yang jelas harus dinilai pertama karena pada korban tersebut yang paling membutuhkan intervensi untuk penyelamatan nyawa.

\section{Step 2 : ASSES}

Prioritas pertama selama penilaian individu adalah untuk memberikan intervensi menyelamatkan nyawa. Termasuk mengendalikan perdarahan utama; membuka jalan napas pasien, dekompresi dada pasien dengan pneumotoraks, dan menyediakan penangkal untuk eksposur kimia. Intervensi ini diidentifikasi karena injury tersebut dapat dilakukan dengan cepat dan dapat memiliki dampak yang signifikan pada kelangsungan hidup pasien. Intervensi live saving yang harus diselesaikan sebelum menetapkan kategori triase dan hanya boleh dilakukan dalam praktek lingkup responder dan jika peralatan sudah tersedia.

Setelah intervensi menyelamatkan nyawa disediakan, pasien diprioritaskan untuk pengobatan berdasarkan ke salah satu dari lima warna-kode kategori. Pasien yang mengalami luka ringan yang self-limited jika tidak diobati dan dapat mentolerir penundaan dalam perawatan tanpa meningkatkan risiko kematian harus diprioritaskan sebagai minimal dan harus ditunjuk dengan warna hijau. Pasien yang tidak bernapas bahkan setelah intervensi live saving yang diprioritaskan sebagai mati dan harus diberi warna hitam. Pasien yang tidak mematuhi perintah, atau tidak memiliki pulsa perifer, atau dalam gangguan pernapasan, atau perdarahan besar yang tidak terkendali harus diprioritaskan immediate dan harus ditunjuk dengan warna merah. Penyedia harus mempertimbangkan apakah pasien ini memiliki cedera yang mungkin tidak sesuai dengan kehidupan yang diberikan sumber daya yang tersedia, jika ada, maka provider harus triase pasien sebagai expectant /hamil dan harus ditunjuk dengan warna abu-abu. Para pasien yang tersisa harus diprioritaskan sebagai delayed dan harus ditunjuk dengan warna kuning. 


\section{Model START/ JUMPSTART Triage Untuk Insiden Korban Masal (Mass Casualty}

Incident)

\section{Model START}

Stein, L., 2008 menjelaskan Sistem START tidak harus dilakukan oleh penyedia layanan kesehatan yang sangat terampil. Bahkan, dapat dilakukan oleh penyedia dengan tingkat pertolongan pertama pelatihan. Tujuannya adalah untuk dengan cepat mengidentifikasi individu yang membutuhkan perawatan, waktu yang dibutuhkan untuk triase setiap korban kurang dari 60 detik. START membagi korban menjadi 4 kelompok dan masing-masing memberikan mengelompokkan warna. START triase memiliki tag empat warna untuk mengidentifikasi status korban. Langkah pertama adalah meminta semua korban yang membutuhkan perhatian untuk pindah ke daerah perawatan. Ini mengidentifikasi semua korban dengan luka ringan yang mampu merespon perintah dan berjalan singkat jarak ke area pengobatan. Ini adalah GREEN kelompok dan diidentifikasi untuk pengobatan delayed, mereka memang membutuhkan perhatian. Jika anggota kelompok ini tidak merasa bahwa mereka yang menerima pengobatan mereka sendiri akan menyebarkan ke rumah sakit pilihan mereka. Langkah selanjutnya menilai pernapasan. Jika respirasi lebih besar dari 30 tag korban sebagai RED (Immediate), jika tidak ada reposisi respirasi jalan napas. Jika tidak ada respirasi setelah reposisi untuk membuka jalan napas, tag korban BLACK (mati). Jika tingkat pernapasan kurang dari 30 bpm, periksa denyut nadi radial dan refill kapiler. Jika tidak ada pulsa radial teraba atau jika kapiler isi ulang lebih besar dari 2 detik, menandai korban RED (Immediate). Jika ada perdarahan yang jelas, maka kontrol perdarahan dengan tekanan. Minta orang lain, bahkan korban GREEN untuk menerapkan tekanan dan melanjutkan untuk triase dan tag individu. Jika ada nadi radial, nilai status mental korban dengan meminta mereka untuk mengikuti perintah sederhana seperti meremas tangan. Jika mereka tidak bisa mengikuti perintah sederhana, maka tag mereka RED (Immediate) dan jika mereka dapat mengikuti perintah sederhana, maka tag mereka YELLOW (delayed).

Algoritma dibawah ini membuat lebih mudah untuk mengikuti. Pemeriksaan tiga parameter, pernapasan, perfusi dan status mental kelompok dapat dengan cepat diprioritaskan atau disortir menjadi 4 kelompok warna berdasarkan apakah mereka membutuhkan intervensi langsung yang kelompok RED, intervensi tertunda (sampai satu jam) yang merupakan kelompok YELLOW, luka ringan dimana intervensi dapat ditunda hingga tiga jam yang adalah kelompok GREEN dan mereka yang mati yang 
kelompok BLACK. Tujuannya adalah untuk mengidentifikasi dan menghapus mereka yang membutuhkan perhatian yang paling mendesak. Pada kelompok YELLOW dan GREEN perlu dinilai kembali untuk menentukan apakah status mereka berubah.

\section{START - Simple Triage And Rapid Treatment}

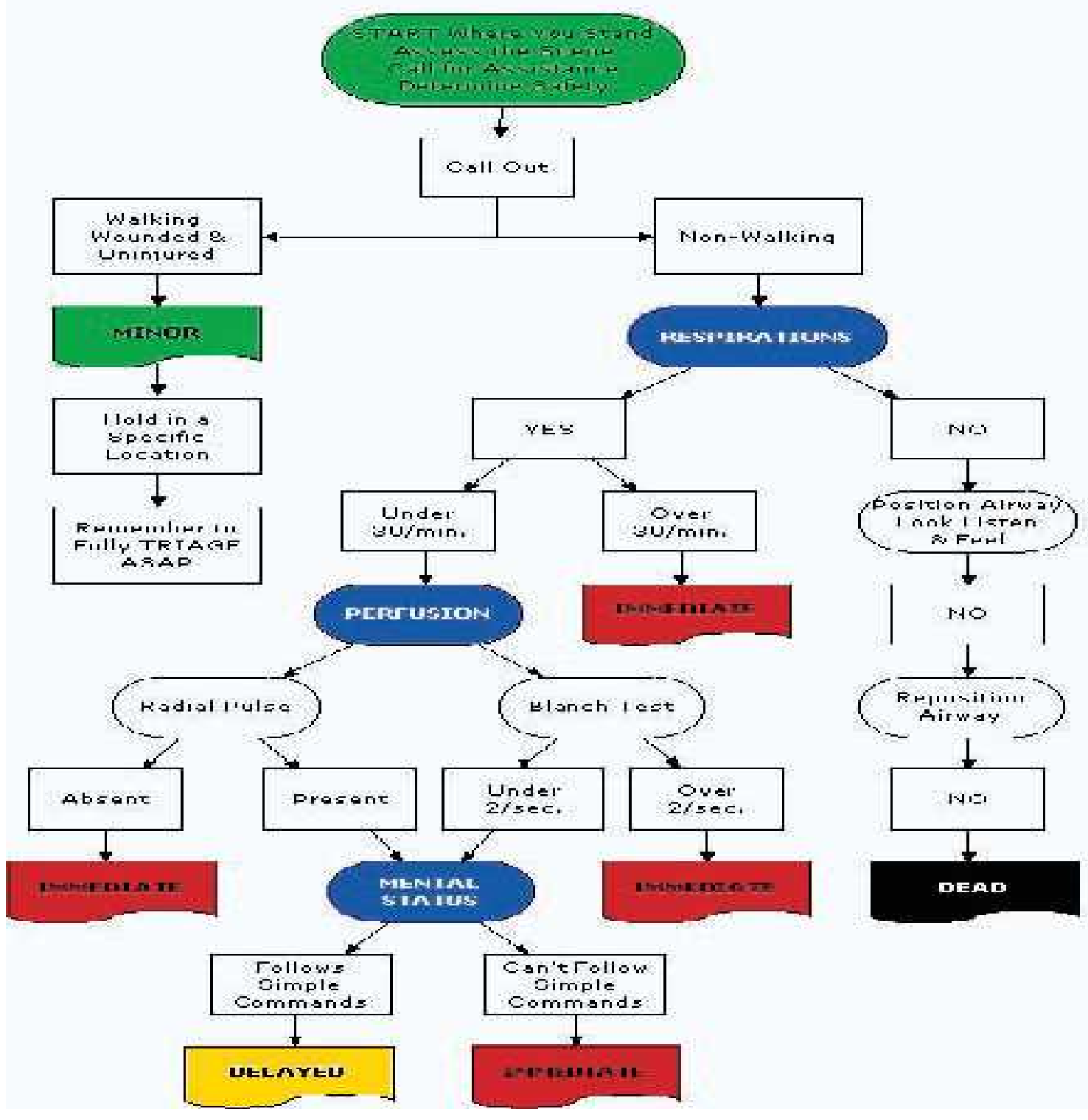

Gambar 2. Model START Triage

\section{JUMPSTART}

Anak-anak memiliki nilai rentang normal yang berbeda dari yang pernapasan tergantung pada usia mereka, sehingga metode START berdasarkan tingkat pernapasan 30 tidak akan sesuai untuk anak-anak. Selain itu, anak-anak lebih cenderung memiliki masalah pernapasan utama sebagai lawan masalah kardiovaskular dan anak-anak yang tidak bernapas mungkin hanya memerlukan pernapasan buatan untuk diresusitasi. Selain 
itu, anak-anak mungkin tidak mudah dibagi sesuai dengan yang dapat berjalan kaki ke lokasi yang ditunjuk karena perkembangan, keterampilan, kesediaan mereka untuk meninggalkan orangtua terluka dan kecenderungan orang tua untuk membawa anak.

Hal ini digunakan secara luas di Amerika Serikat dan Kanada dan merupakan modifikasi sistem START.. Alat ini digunakan untuk anak-anak usia 1 dan 8 tahun. Mungkin tidak mudah untuk menentukan usia anak sehingga korban tampak masih anakanak maka menggunakan JUMPSTART dan jika korban terlihat seperti orang dewasa muda menggunakan START. Modifikasi dan penilaian tambahan akan diperlukan untuk anakanak kurang dari usia 1 tahun, denganketerlambatan perkembangan, cacat kronis atau cedera terjadi sebelum kejadian. (Jumpstart, 2008 dalam Stein, L., 2008)

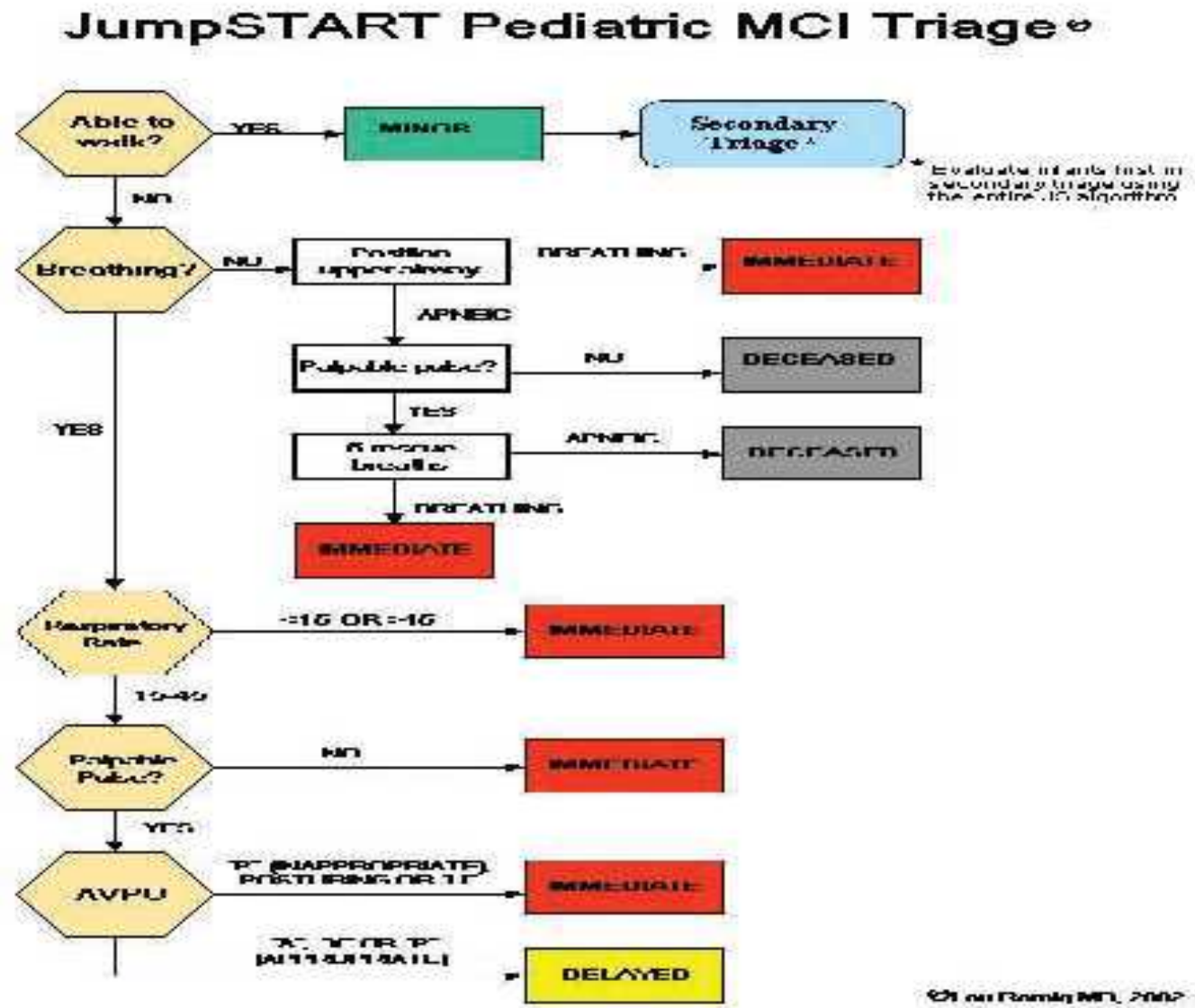

Gambar 3. Model Jump START Triage

\section{SALT Triage Sebagai Triage Prehospital}

Penelitian oleh Cone et al (2009) dengan menilai keakuratan dan kecepatan 2 paramedic dalam menerapkan triage $S A L T$ pada 52 korban scenario. Hasil triage $S A L T$ oleh kedua paramedic tersebut adalah benar untuk 41 dari 52 pasien (78,8\% akurasi). Tujuh pasien dimaksudkan untuk menjadi T2 yang diprioritaskan sebagai T1, dan dua pasien 
dimaksudkan untuk menjadi T3 diprioritaskan sebagai T2, untuk tingkat overtriage 13,5\%. Dua pasien dimaksudkan untuk menjadi T2 yang diprioritaskan sebagai T3, untuk tingkat undertriage dari 3,8\%. Triage dicatat oleh pengamat selama 42 dari 52 pasien, dengan ratarata 15 detik per pasien (kisaran 5-57 detik). Kesimpulannya SALT dapat diterapkan dengan cepat dilapangan dan aman. Penilaian tingkat undertriage yang rendah. Hasil overtriage signifikan dan masih bisa diterima.

Pada penelitian Lerner, E.B,. Schwartz, R.B., Coule, P.L., Pirrallo, R.G., (2010) dengan metode simulasi SALT triage pada 73 peserta pelatihan program bencana masal. Hasil menunjukkan 217 observasi korban. Awal triase adalah benar untuk $81 \%$ dari pengamatan, $8 \%$ overtriaged dan $11 \%$ berada di undertriage. Triage terakhir adalah benar untuk $83 \%$ dari pengamatan, $6 \%$ yang overtriage dan $10 \%$ undertriage. Interval triase ratarata adalah 28 detik ( \pm 22 ; kisaran: 4-94). 9\% melaporkan bahwa sebelum pelatihan mereka merasa sangat percaya diri menggunakan SALT triase dan 33\% tidak percaya diri. Setelah pelatihan, tidak ada yang melaporkan tidak merasa percaya diri menggunakan SALT triase, $26 \%$ berada pada tingkat yang sama kepercayaan, $74 \%$ merasa lebih percaya diri, dan tidak ada yang merasa kurang percaya diri. Sebelum pelatihan, 53\% dari responden merasa SALT triase adalah lebih mudah digunakan daripada triase bencana mereka protokol saat ini, 44\% merasa itu mirip, dan 3\% merasa itu lebih sulit. Setelah pelatihan tidak ada yang melaporkan bahwa SALT triase lebih sulit untuk digunakan.

\section{START/JUMPSTART Triage sebagai triage prehospital}

Analisis retrospective oleh Kahn, Schultz, Miller dan Anderson (2008) mengevaluasi triage START pada bencana kecelakaan kereta api tahun 2003. Review dilakukan pada 148 catatan di 14 rumah sakit penerima korban. Pengamatan mulai korban diberi kategori triage, kesesuaian triage dan waktu tiba di rumah sakit. Hasil didapatkan korban kategori merah (immediate) 22, kuning (delayed) 68, hijau (minimal) 58. Berdasarkan kesesuaian hasil triage sebenarnya adalah 2 merah, 26 kuning, dan hijau 120 pasien. 79 pasien overtriaged, 3 yang undertriaged, dan hasil 66 pasien cocok tingkat triagenya. Tidak ada triage yang mendekati sensivitas 90\% dan 90\% kebutuhan sensitivitas yang ditetapkan dalam hipotesis, meskipun merah adalah 100\% sensitif (95\% confidence interval [CI] 16\% sampai 100\%) dan hijau adalah 89,3\% spesifik (95\% CI 72\% sampai 98\%). Statistik Obuchowski adalah 0,81, berarti bahwa korban dari kelompok akuisi tinggi memiliki peluang $81 \%$ untuk kategori triase akuisi tinggi. Median waktu kedatangan untuk pasien merah adalah lebih dari 1 jam lebih awal dari pasien lain. 


\section{Analisis perbandingan model SALT dengan START/JUMPSTART triage untuk insiden korban masal (Mass Casualty Incident)}

Penerapan metode triage SALT maupun START/JUMPSTART telah disepakati di Amerika Serikat dalam rangka penyeragaman dan menstandarkan dalam pemilahan kategori pasien (Lee, C.H., 2010). Dari kedua metode tersebut menggunakan tingkat triage dan coding warna untuk mengkategorikan korban bencana, yaitu :

o Triase Tag Merah ("Segera-Immediate" atau T1 atau Prioritas 1): Pasien yang hidupnya berada dalam bahaya langsung dan yang membutuhkan pengobatan segera

○ Triase Tag Kuning ("tertunda-delayed" atau T2 atau Prioritas 2): Pasien yang hidupnya tidak dalam bahaya langsung dan siapa yang akan membutuhkan mendesak, tidak langsung, perawatan medis

- Triase Tag hijau ("Minimal" atau T3 atau Prioritas 3): Pasien dengan luka ringan yang akhirnya akan memerlukan pengobatan

○ Tag Triase hitam ("hamil-expectant" atau Tidak Prioritas): Pasien yang mati atau yang memiliki luka yang luas sehingga mereka tidak bisa diselamatkan dengan sumber daya terbatas yang tersedia.

Hal ini juga penting untuk dicatat bahwa pasien perlu ditinjau kembali, dan awal sebutan triase kode warna dapat berubah seiring waktu. Berdasarkan review penelitian Kahn, Schultz, Miller, Anderson (2008), Cone et al (2009), dan Lerner, E.B,. Schwartz, R.B., Coule, P.L., Pirrallo, R.G., (2010) bahwa metode START terdapat sedikit data tentang keefektifan pengkategorian dan ada beberapa bukti bahwa START dapat menyebabkan overtriage pasien (misalnya, penandaan pasien sebagai "Immediate" yang dalam kenyataannya harus diberi label "delayed") dalam pengkategorian korban massal, sedangkan pada metode SALT lebih mudah dipelajari dan diaplikasikan, mudah diingat, korban dalam jumlah besar lebih cepat dalam pemilahan dan penanganan, berlaku untuk semua tipe bencana dan populasi.

\section{Penutup}

Insiden korban masal merupakan kondisi dimana sumber daya dalam merespon bencana kurang memadai daripada kebutuhannya. Masalah tinggi angka kematian / kecacatan korban disebabkan keterlambatan mentransfer korban dari lokasi kejadian ke rumah sakit terdekat, atau kekeliruan ketika mengkategorikan korban pada saat triage, bisa 
overtriage maupun undertriage. Oleh karena itu diperlukan pendekatan yang efektif dalam penanganan korban melalui metode triage cepat dan efektif di tempat kejadian (prehospital) dalam insiden korban masal.

\section{Daftar Pustaka}

Cone et al, (2009). Pilot Test Of The Salt Mass Casualty Triage System. Prehospital Emergency Care 2009;13:536-540.

Deluhery, M.R., Lerner, E.B., Pirrallo, R.G., Schwartz, R.B., (2011). Paramedic Accuracy Using Salt Triage After A Brief Initial Training. Prehospital Emergency Care 2011;15:526-532

Kahn, Schultz, Miller dan Anderson, (2008). Does START Triage Work? An Outcomes Assessment After a Disaster. Annals of Emergency Medicine Volume 54, Issue 3, Pages 424-430.e1, September 2009

Lee, C.H., (2010). Disaster and Mass Casualty Triage. American Medical Association Journal of Ethics. June 2010, Volume 12, Number 6: 466-470.

Lee, Et al. (2011). The validity of the Canadian Triage and Acuity Scale in predicting resource utilization and the need for immediate life-saving interventions in elderly emergency department patients. Scandinavian of Journal Trauma, Resucitation and Emergency Medicine. 19 : 68. p 1-8.

Lerner et al. Dalam Neal, D.J. (2009). Prehospital Patient Triage In Mass Casualty Incidents: An Engineering Management Analysis And Prototype Strategy Recommendation. (A Dissertation Submitted To The Faculty Of The School Of Engineering And Applied Science Of The George Washington University In Partial Satisfaction of the requirements for the degree of Doctor of Science May 17, 2009). Retrieved from http://gradworks.umi.com/3352839.pdf date 14 mei 2013.

Lerner, E.B,. Schwartz, R.B., Coule, P.L., Pirrallo, R.G., (2010). Use Of Salt Triage In A Simulated Mass-Casualty Incident. Prehospital emergency care 2010;14:21-25

Mace, Sharon E and Mayer, Thom A. (2013). Triage. Chapter 15. Section IV. The Practice Environment.

Stein, L., (2008). Mass Casualty Triage. The Oklahoma Nurse. P 18-21. 